\title{
NEW MEDIA AND DEMOCRATIC CULTURE: A STUDY OF INDONESIA'S ANTI-GRAFT 'FACEBOOK MOVEMENT' 2009 AS THE NEW 'NON-PARTY' POLITICS IN INDONESIA
}

\author{
Masduki \\ Islamic University of Indonesia
}

\begin{abstract}
Internet or Social Network Site is a new media facilitating collective action and a "public sphere" for political and social interactions. The Internet is not only a big marketplace. Blogs, wikis and other social networking sites provide a technological basis for grassroots action to coordinate and communicate. Movement of 1,000,000 Facebookers Supporting Chandra Hamzah and Bibit Samad Riyanto in Indonesia 2009, was launched after the two suspended Corruption Eradication Commission (KPK) officers were arrested on suspicion of abuse of power. This, become an interesting new phenomenon in Indonesia. It is an example of widespread popular support for the anticorruption leaders and the antigraft movement.

My paper aims to explore the development of social media in Indonesia and its contribution to implementation of transparency and antigraft movement. Particularly, the paper will identify the role of Facebook in establishing a non political party, online parliament and the future of it in Indonesia as the democratic moslem country in the world.

Many active discussions has been generated along 2000s on the topic of social media and its effect on the formation and mobilization of social and political movement. For example, the emergence of the Coffee Party in US. Since 2009, Facebook in Indonesia has played an important role in politics and its importance was first noticed by KPK case. Since then there has been growth in the role of Facebook in political movements. The power of civil society in the form of Facebookers replaces democratic checks and balance which in the real world should be the function of political parties in Indonesian parliament.
\end{abstract}

Keyword: Social Media, Facebook, Anti-graft Movement, Public Sphere 


\section{A. Introduction}

Internet or Social Network Site is a new media facilitating collective action in ways never thought possible. Internet is "public sphere" for political and social interactions. Although the broader political climate may have a powerful influence on the success or failure of emerging social and political movement, the net is enabling groups previously incapable of political action to express their voices. Through internet, especially Facebook, Indonesian people are now able to better locate and converse with each other via Facebook. As a result, the distance between talk and organized action has grown smaller.

Generally, Facebook (FB) is a locus for all types of groups to communicate, collaborate, and cooperate. This technology is, in principle, value neutral: it can be a channel for both positive and negative interest. Internet is a place for people with a wide range of interests including radical groups, non-political party groups interested in fomenting social and political movement. My paper aims to explore the development of digital social media communities as non-party politics in Indonesia, especially facebookers through Facebook, their contribution and obstacles to implement democratic culture, transparency and antigraft movement. This is particularly based on 2009 year cases. The paper will identify the role of new media in establishing a non-political party, 'online parliament' and the future of its phenomenon in Indonesia.

\section{SNS Phenomena in Indonesia}

During 2009, there was hardest competition amongst Social Networks Sites or SNS a term used by Nicole B. Ellison of Michigan State Universityor digital social networks in Southeast Asia'. Friendster is the largest social network with about 65 million users. Following Friendster is Facebook (14 million), MySpace (15 million), CyWorld (Korea, 14 million), Hi5 (10 million), Orkut (10 million),

${ }^{1}$ According to Ellison, social network sites are web-based services that allow individuals to (1) construct a public or semi-public profile within a bounded system, (2) articulate a list of other users with whom they share a connection, and (3) view and traverse their list of connections and those made by others within the system. The nature and nomenclature of these connections may vary from site to site. The term "social network site" also appears in public discourse, and the two terms are often used interchangeably. "Networking" emphasizes relationship initiation, often between strangers. While networking is possible on these sites, it is not the primary practice on many of them, nor is it what differentiates them from other forms of computer-mediated communication (CMC). 
and Xiaonei (China, 5 million. In Indonesia, Friendster was the first social network to translate into Indonesian language in March of 2008.

In 2008, Indonesia had been the fastest growing country on Facebook ${ }^{2}$ in Southeast Asia, outpacing its growth in China, India, Malaysia, Thailand, and Singapore. The 22.378.640 Indonesians on Facebook are a small minority in their own country. With $0.4 \%$ penetration, they represent just a small portion of the of 240 million people througout the country. In September 2009, facebook users had become 8.520 .160 people, with 8.23 millions were new users. The growth of FB users by month can be explained as follows:

\begin{tabular}{|cll|}
\hline No & Month & User \\
\hline 1 & September 2009 & 8.520 .160 \\
2 & October 2009 & 9.713 .580 \\
3 & November 2009 & 12.189 .100 \\
4 & December 2009 & 13.870 .120 \\
5 & February 2010 & 17.301 .760 \\
6 & March 2010 & 19.094 .640 \\
7 & April 15, 2010 & 22.378 .640 \\
\hline
\end{tabular}

Source: www facebookcom

According to Global Monitor report 2009, Facebook grew from 44 million to 50 million in Asia, and mostly in three countries. The Philippines grew by 1.38 million people to 5.78 million monthly active users; Taiwan grew by nearly as many people, seeing a massive surge of 1.37 million to reach 3.32 million; Indonesia, already the largest Facebook country in Asia, grew by 1.19 million to reach 13.9 million monthly actives. In comparison, below explained the top 30 countries with highest number of Facebook users in the world up to December 2009:

2. Facebook (FB) is the name of a popular social networking site (SNS) that connects people with friends and others who work, study and live around them. Traditionally, people use Facebook to keep in touch with friends, post photos, share links and exchange other information. Facebook is a social networking website that was originally designed for college students, but is now open to anyone 13 years of age or older. Facebook users can create and customize their own profiles with photos, videos, and information about themselves. Friends can browse the profiles of other friends and write messages on their pages. Each Facebook profile has a "wall," where friends can post comments. Since the wall is viewable by all the user's friends, wall postings are basically a public sphere. 


\begin{tabular}{|c|c|c|c|c|}
\hline Rank & Country & $\begin{array}{c}\text { Number of Facebook } \\
\text { users }\end{array}$ & $\begin{array}{l}12 \text { month } \\
\text { growth \% }\end{array}$ & $\begin{array}{c}6 \text { month growth } \\
\%\end{array}$ \\
\hline 1 & $\overline{\text { USA }}$ & $101,303,240$ & $140.8 \%$ & $46.0 \%$ \\
\hline 2 & UK & $22,625,300$ & $51.5 \%$ & $20.9 \%$ \\
\hline 3 & Turkey & $16,943,780$ & $113.6 \%$ & $36.8 \%$ \\
\hline 4 & Indonesia & $14,681,580$ & $1536.7 \%$ & $126 \%$ \\
\hline 5 & France & $14,290,700$ & $117 \%$ & $32.6 \%$ \\
\hline 6 & Canada & $14,228,460$ & $31 \%$ & $19 \%$ \\
\hline 7 & Italy & $13,272,760$ & $137.6 \%$ & $30 \%$ \\
\hline 8 & Philippines & $8,387,560$ & $2046.8 \%$ & $208.4 \%$ \\
\hline 9 & Spain & $7,701,200$ & $196.7 \%$ & $33.4 \%$ \\
\hline 10 & Australia & $7,611,920$ & $75.8 \%$ & $25.7 \%$ \\
\hline 11 & Argentina & $7,387,120$ & $227.5 \%$ & $50.6 \%$ \\
\hline 12 & Colombia & $7,243,520$ & $99.4 \%$ & $25.8 \%$ \\
\hline 13 & Mexico & $6,505,040$ & $351.5 \%$ & $78.5 \%$ \\
\hline 14 & Chile & $5,808,020$ & $39.9 \%$ & $20.2 \%$ \\
\hline 15 & Germany & $5,799,520$ & $361.9 \%$ & $84.9 \%$ \\
\hline 16 & Taiwan & $5,490,300$ & $4763 \%$ & $701 \%$ \\
\hline 17 & India & $5,397,480$ & $403.8 \%$ & $66.8 \%$ \\
\hline 18 & Venezuela & $4,952,340$ & $164.2 \%$ & $38.4 \%$ \\
\hline 19 & Malaysia & $3,975,640$ & $367.5 \%$ & $99.3 \%$ \\
\hline 20 & Sweden & $3,066,180$ & $80.7 \%$ & $34.1 \%$ \\
\hline 21 & Belgium & $2,872,160$ & $73.5 \%$ & $21.1 \%$ \\
\hline 22 & Hong Kong & $2,727,980$ & $87.0 \%$ & $30.7 \%$ \\
\hline 23 & South Africa & $2,434,500$ & $164.6 \%$ & $41.5 \%$ \\
\hline 24 & Brazil & $2,413,900$ & $1052.4 \%$ & $137.7 \%$ \\
\hline 25 & Egypt & $2,341,880$ & $184.7 \%$ & $44.7 \%$ \\
\hline 26 & Denmark & $2,262,260$ & $27.4 \%$ & $15.3 \%$ \\
\hline 27 & Norway & $2,256,080$ & $54.9 \%$ & $21.7 \%$ \\
\hline 28 & Greece & $2,222,860$ & $122.4 \%$ & $35.6 \%$ \\
\hline 29 & Israel & $2,149,500$ & $149.5 \%$ & $49.9 \%$ \\
\hline 30 & Thailand & $1,963,560$ & $1063.8 \%$ & $181.6 \%$ \\
\hline
\end{tabular}




\section{The Emergence of "New Political Movement"}

Digital technologies highlight the cultural and participatory features of freedom of expression including political movement. The purpose of freedom of speech is to promote a democratic culture. A democratic culture is more than representative institutions of democracy, and it is more than deliberation about public issues. Rather, a democratic culture is a culture in which individuals have a fair opportunity to participate in the forms of meaning making that constitute them as individuals. Democratic culture is about individual liberty as well as collective self-governance; it is about each individual's ability to participate in the production and distribution of culture. Freedom of speech allows ordinary people to participate freely in the spread of ideas and in the creation of meanings that, in turn, help constitute them as persons. The digital age provides a technological infrastructure that greatly expands the possibilities for individual's participation in the growth and spread of culture and thus greatly expands the possibilities for the realization of a truly democratic culture (Balkin, 2004).

Facebook could be a new medium of social and political movement. Political movements is a type of group action. The largest informal groupings of individuals and/or organizations focused on specific political or social issues, on carrying out, resisting or undoing a social and political policy. Modern social movements became possible through education, ICT network and increased mobility of people virtually due to the industrialization and urbanization of 20th century societies. The heterarchical, decentralized and likewise open architecture of the Internet provides the necessary precondition for virtual communities and hence for participation, new social movements and cyber-protest to emerge. The social media has "real potential for enabling democratic forms of decision-making and beneficial instances of collective action". In addition, social software can be used for different purposes as well, dependent on the targets and causes of a community.

Christian Fuchs (2006: 293) argues the Internet is not only a big marketplace, it is also a space of political interaction. Blogs, wikis and social networking sites provide a technological basis for grassroots action to coordinate and for participants to communicate. Chat rooms, email and mobile gadgets enable ad-hoc activities to emerge. The Internet can support the movement of topicoriented pressure groups, protest groups and ideological movements outside the 
mainstream since civil society has the opportunity to engage in political participation without the guidance of institutions.

Fuchs describes "cyber-protest" as an emerging field of social movement research that reflects the role of alternative online media, online protests, and online protest communication in society." Facebooker is a new generation of skilled web users with increasing computer competences that is able to use social software for organizing grassroots action. The freer distributed power of Facebook networks is essential for the political action since they make grassroots activities possible.

Political science and sociology have developed a variety of theories and empirical research on social and political movements. For example, some researches in political science highlight the relation between popular movements and the formation of new political parties as well as discussing the function of social movements in relation to agenda setting and influence on day to day politics. Modern movements, such as anti-graft campaign, have utilized technology and the internet to mobilize people globally.

Adapting to communication trends is a common theme among successful movements. Using technology, the Borgen Project ${ }^{3}$ fights global poverty. They look for solutions to end poverty, they look into security for poverty, and they look at policies that create poverty. This group is breaking away from Marx's idea of a rigged social structure and trying to prevent poverty and a poor class in society.

As well as political movement, social movements are a major vehicle for ordinary people's participation in public politics (Tilly, 2004:3). Tilly's argument is that there are three major elements to a social movement: (1) Campaigns: a sustained, organized public effort making collective claims of target authorities; (2) Repertoire: employment of combinations from among the following forms of political action: creation of special-purpose associations and coalitions, public meetings, solemn processions, vigils, rallies, demonstrations, petition drives, statements to and in public media, and pamphleteering; and (3) Participants' concerted public representation of worthiness, unity, numbers, and commitments on the part of themselves and/or their constituencies.

\footnotetext{
${ }^{3}$ The Borgen Project is known for being tech savvy, non-partisan and having access to USA congressional leaders on a national level. The Borgen Project is creating a political foree for the world's poor. It is building an influential ally for the most neglected, ignored and destitute people on the world and building a powerful povertyreduction movement that can champion humanitarian causes.
} 
Based on David Aberle's observation, types of social movement are :

How much change?

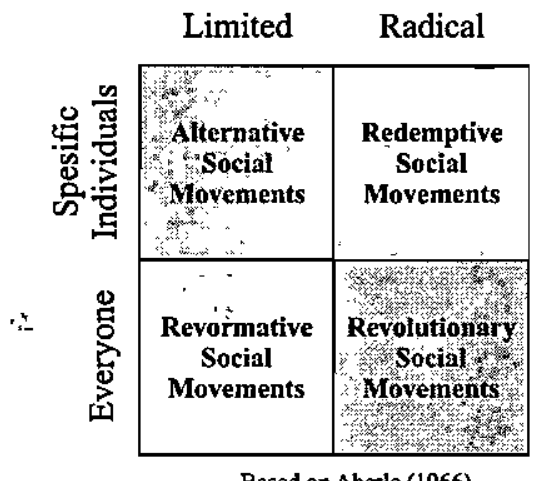

Based on Abetle (1966)

(Source : David E. Aberle, 1966)

Sociologists distinguish between several types of social and political movement. In terms of scope, social and political movement could be divided into two ares. (1) Reform movements, movements dedicated to changing some norms. Examples of such is a green movement advocating a set of ecological laws, or a movement supporting introduction of a capital punishment or right to abortion. Some reform movements may advocate a change in custom and moral norms, for example, condemnation of pornography or proliferation of some religions.

The nature of such movements is not just related to the issue but also to the methods used. There could be reformist or radical methods used to achieve the same end, such as in the case of making abortion legal and readily available. (2) Radical movement, movements dedicated to changing value systems. Those involve fundamental changes, unlike the reform movements. These for examples would include the American Civil Rights Movement which demanded full civil rights and equality under the law to all Americans regardless of race or the reform movement which demanded the transformation of a Soeharto's political and economic system into a democracy in Indonesia.

Generally, there is the importance of resources in social movement development. Resources include: knowledge, money, media, labor, solidarity, legitimacy, and internal and external support from ordinary people. The social movements develop when individuals with grievances are able to mobilize 
sufficient resources to take action. Actors are rational; they weigh the costs and benefits from movement participation. Members are recruited through networks; commitment is maintained by building a collective identity and continuing to nurture interpersonal relationships. Movement is contingent upon the aggregation of resources.

Social movements have been and continued to be closely connected with democratic political systems. In other word, a political movement is a social movement in the area of politics. Social dan political movements have been involved in democratizing nations, but more often they have flourished after democratization. A political movement may be organized around a single issue or set of issues, or around a set of shared concerns of a social group. In contrast with a political party, a non-political movement is not organized to elect members of the movement to government office; but aims to convince citizens and/or government officers to take action on the issues and concerns which are the focus of the movement.

Political movements are expressions of the struggle of a social group for the political space and benefits. They are presented mostly by non-state groups. In fact the process of the construction of identities and reinforcing them is also a part of political movements. A political movement may be local, regional, national, or international in scope. Some have aimed to change government policy, such as the anti-war movement, the Ecology movement, and the Anti-globalization movement. Many have aimed to establish or broaden the rights of subordinate groups, such as anti-graft, the women's suffrage movement, gay rights movement, the disability rights movement, or the inclusive human rights movement.

\section{Social Media for Political Interest}

There are many active discussions that have been generated since 2000 s on the topic of social media and its effect on the formation and mobilization of social and political movement. For example, the emergence of the Coffee Party ${ }^{4}$ first appeared on the social networking site, Facebook. The party has continued to gather membership and support through that site and file sharing sites, such as

${ }^{4}$ The Coffee Party USA is a political movement that developed as an altemative to the Tea Party movement. Its mission states that it is based on the underlying principle that the government is "not the enemy of the people, but the expression of our collective will, and that we must participate in the democratic process in order to address the challenges we face as Americans." Its slogan is "Wake Up and Stand Up". Its stated goals include getting cooperation in government and removing corporate influence from politics. The Coffee Party USA was 
Flickr. In Indonesia, there is a tendency of non-party actors to influence electoral politics and regular public policies. There is a serious debates on the role of interest groups and independent citizens in contemporary election process.

The day-to-day government policy process is, in many ways, far from accessebility of ordinary people. In general election cases, the active involvement of non-party actors appears in the process of policy making is essential. These actors' interest groups, individual citizen operate in the campaign environment independently of the parties and their candidates. They are not seeking to attain public office, but for the most part, they seek to influence electoral outcomes to their advantage, and yet on occasions for less selfish reasons such as increasing the quality of the electoral process itself.

The government, crooked cops or overzealous prosecutors may have little to fear from massive street demonstrations, but the legions of people who have made Facebook the nunber one website in Indonesia are something else entirely.

Since the fall of authoritarian regime led by General Suharto, Indonesian civil society has more leverage in the public domain, especially through online media. The crisis of the relationship between the bases of social groups and the political parties makes civil society a non-determinant player in the formulation of legislation and public policy.

The emergence of cyber and physical civic spaces started during and after the political reform of 1998 . The case of the May 1998 popular activism against the state to show how cyberspace provides an opening for political activism to, first, break through the barriers of state monopoly over the production of knowledge and flows of information and, second, to reach a national and even international audience through the cascading of information from the Internet to people on the street using other media technologies.

established in January, 2010, on the Facebook social networking site. It was founded by documentary filmmakers and political activists Annabel Park and Eric Byler.

After becoming increasingly frustrated with the incivility and obstructionism in political discourse, and the media narrative that the Tea Party represented America, Park vented her anger on her Facebook page. The group rapidly grew to over 155,000 in size from word of mouth and social networking in under six weeks. The Coffee Party held their initial national coffec house day event on March 13, 2010. Some 370 events took place across the US and the world, including Tokyo and Jakarta, with the intent to "encourage our existing and soon-toform chapters to facilitate informative and civil dialogue about issues that affect all of us, collectively." 
On October-November 2009, when more than one million of Facebookers (about 1,010,000) members of the social network Facebook - rallied to protest the detention of the leaders of Indonesia's Anti-Corruption Commission (KPK), Susilo Bambang Yudhoyono, Indonesian president, became seriously concerned about the power of Facebook. Concerned that this movement may have the potential to overthrow him, he took action in the KPK case by setting up an independent team to assess whether the detention violated due process of law.

Since 2009, Facebook in Indonesia has played an important role in politics and its importance was first noticed by KPK case. Since then there has been growth in the role of Facebook in political movements. Does anyone doubt that Indonesians are fed up with corruption, terrorism or injustice? The facts are there for all to see in the hundreds of thousands of people speaking their minds on Facebook. Acording to Globe Asia, a Jakarta based political magazine, three events that symbolized the rise of social media politics in Indonesia are:

\section{IndonesiaUnite}

Within seconds of the twin bombs exploding at Jakarta's posh JW Marriott and the Ritz-Carlton hotels on the morning of July 17, 2009, Twitter and Facebook were lighting up with information, pictures, reactions, condemnations and condolences. On YouTube, a social network user Pandji Pragiwaksono released a music video called "Kami Tidak Takut" (We Are Not Afraid), which was widely circulated. After the terrorist bombings, with business back to normal, Indonesia Unite remains an active Facebook group spawning all manner of commentary on the country from ethnic cuisines to social causes, cultural heritage and holiday destinations.

\section{Supporting Prita Mulyasari}

With housewife Prita Mulyasari finally acquitted of criminal defamation charges for the e-mail she sent to friends criticizing the service she received at Omni Hospital, it almost seems as if she has been in the news forever. But the 32year old mother of two rose to such prominence largely because of Facebook. A few days after the Tangerang District Court ruled in the hospital's favor in a civil case and fined Prita $\$ 33,072$, the prosecutors upped the ante and on May 13, 2009 charged her under the Electronic Information and Transaction (ITE) law, which allowed the police to imprison her while she awaited a criminal defamation trial that only concluded on Tuesday. Prita spent three weeks behind bars before Facebook came to her rescue. 


\section{Anti-graft Movement}

Gerakan 1.000.000 Facebookers Dukung Chandra Hamzah dan Bibit Samad Riyanto (Movement of 1,000,000 Facebookers Supporting Chandra Hamzah and Bibit Samad Rianto) was the biggest political movement in terms of social and political effects. The Facebook page was created by Usman Yasin on October 29, 2009 the same day Chandra and Bibit were arrested by the National Police. It featured the logo of the "gecko vs crocodile" a term first made popular by former Indonesian national police chief of detectives Susno Duadji when he referred to the rivalry between the police and the KPK. The face-off between the police and the KPK over Chandra and Bibit became the most gripping event in the nation in the 2009 following their arrest, forcing Yudhoyono to step into the fray and "suggest" that the police and the Attorney General's Office drop the case, which they did.

What we can learn from above cases? The power of civil society in the form of Facebookers replaces democratic checks and balance which in the real world should be the function of political parties in parliament. This movement has earned the nickname "on-line parliament" or "new politics". This refers to an idea or a conviction of individuals or groups outside political parties who want to democratize the country, without taking control of state power itself. Their duty is to correct errors of market failures and the failure of 'good governance', especially corruption.

The anti-graft-rallies that were organized via Facebook in Jakarta 2009 and carried out in many cities in Indonesia serve as one example for global political activism. The protest underlines the theoretical concepts of political movement through information and communication technologies in general and cyber-protest in particular: (1) the foundation for community building, (2) the interrelation of the real and the virtual space.

In the history of military dictatorships in Latin America or the totalitarian communist regimes in Eastern Europe, civil society is often said to define "the new politics". This refers to an idea: or a conviction of individuals outside political parties; who want to democratize the country and distribute the power, without taking control of state power itself. The movement of "the new politics" was identified as a new social force emerging after 1968 focusing on issues of peace, environment, women, and human rights. The so-called 'civil society' is expected to be able to correct errors of products from market failures and economic crises, such as the one in Asia as a result of the failure of 'good governance', especially corruption (Hamid, 2009). 
The virtual reality, manifested in the "movement of a million Facebookers was able to influence real life interactions. They can meet the real world of anticorruption activists through their online social interaction. Indonesian Facebookers represent individuals and community groups from various social spectrums, ranging from non-governmental organizations in the field of media, anti-corruption, human rights, peace and religious issues to famous artists, intellectuals, professionals and also ordinary citizens, housewives and local urban communities. They united and thousands rallied in the streets exerting their political will against corruption within the legal system. Their collective demand was to fight corruption.

The phenomenon also rise a democratic culture (Balkin, 2004). A culture which individuals have a fair opportunity to participate in the form of meaningmakings that constitute them as individuals. Democratic culture is about individual liberty. In case of Indonesia, there is renewed hope for a stronger civil society and for democracy. The phenomenon shows a civil society that is actively and critically seeking autonomy. The Facebookers are able to differentiate between the agents of state power and institutions which fall within the domain of the interests and needs of civil society.

According to Christian Fuchs (2008) protestors on the FB produce "shared meanings that constitute collective identities and practices." Social patterns, including social inequalities and imbalanced power relations existing in real space, have an impact on virtual communities and on the organization and outcome of networked political protest.

What was new in 2009 in Indonesia were the political manifestations of social media into areas of traditional activism. BlackBerrys, iPhones and other gadgets are not just status symbols and business tools, they are the new town hall. There are obviously legions of people sitting at their computers who would never think of joining a street protest but who nonetheless have found a convenient and seemingly effective way of making their voices heard in a democracy.

In two national elections, in April 2009 for the House of Representatives and in July 2009 for the presidency, many candidates also treated a FB page as another place to hold a rally. Added to traditional campaign swings and mass gatherings (with paid-for crowds), gamering sympathy online is relatively easy and effective. President SBY also has nearly 500,000 supporters on FB, many of whom are not shy about sharing their criticism of the job he is doing. However, creative minds and mature personalities can do wonders with FB. 


\section{B. Conclusion}

The ability of Internet technology to provide spaces for interpersonal dialogue and in Indonesia post 1998, bolstered the potential for a more democratic public realm. The cyber-civic spaces have further generated a renaissance in the physical landscape of cities to provide social and cultural spaces in the built environment for interaction, debate, and political-cultural continuity and development (Lim, 2001).

The Indonesian anti-graft raflies exemplify how a virtual community can use the specific architecture of the FB to organize itself for political activism that is carried out in real space. In the same way as print-media help to distribute information amongst a more or less locally restricted community the Internet can have the same function on a global scale.

Facebook has the potential to enhance political activism as exemplified in the anti-graft movement. In countries with huge social inequalities, SNS is still used and formed by an elite, and its inherent cultural, social, economic and political structures. The use of FB for political protest or participation is dependent on the ideologies and the cultural and political contexts of its users. Users can either enhance competition, communication or collaboration in cyberspace. Hence technology's potential can be used in different ways and the future direction it takes is dependent on its actors.

Up to 2010, still there are many FB obstacles in terms of political movement such us government's efforts to regulate the internet, block access to what so-called "multimedia content." A new law on information and electronic transactions (ITE) passed in 2008 focuses on what is forbidden by the law, which is set out in section 8: anyone who deliberately and without rights distributes/transmits/makes accessible electronic information/electronic documents with content that violates decency, involves gambling, is libelous, is threatening. Article 28 forbids the spreading of lies over the internet, and hate speech, directed towards particular groups, based on racial, ethnic or religious differences. For both articles violations may lead to imprisonment of up to six years and fines up to 1 billion rupiah $(\$ 110,000)$. 


\section{REFERENCES}

\section{Books and Journals:}

Aberle, David, 1966. The Peyote Religion among the Navaho. Chicago: Aldin

Balkin, Jack M., 2004, Digital Speech and Democratic Culture: A Theory of Freedom of Expression for The Information Society, Yale Law School, USA

Fuchs, Christian, 2008, Internet and Society: Social Theory in the Information Age. New York: Routledge

Hamid, Usman, The New 'Non-party' Politics in Indonesia, Asia-Views, Edition: 35/VI/November/2009

Lim, Merlyna, Cyber-Urban Activism and The Political Change in Indonesia, Annenberg Center for Communication, University of Southern California

Neumayer, Christina, Celina Raffl, Facebook for Protest? The Value of Social Software for Political Activism in the Anti-FARC Rallies, ICT\&S Center, University of Salzburg, Austria, Digi-Active Research Series, December 2008

Tilly, Charles, Social Movements, Boulder, CO, Paradigm Publishers, 2004

\section{Internet Sources:}

Jakarta Post newspaper, Facebook Became the New Town Hall and Twitter the Fastest Media, http://www.thejakartaglobe.com, accessed April 20, 2010

Facebook,Facebook-Indonesia-Outpaces-Southeast-Asian-Counterparts-in2008, http://www.insidefacebook.com/2008, accessed April 20, 2010

Facebook Definition, http://www.techterms.com, accessed April 20, 2010

Borgen Project, http://www.borgenproject.org, accessed April 20,2010

Indonesia Fourth Biggest Face-book Users in the World, http:/www.thejakartapost.com, accessed April 20, 2010

Political Movement, http:/en.wikipedia.org/wiki, accessed April 20, 2010

Ellison, Nicole, Boyd, Danah, Social Network Sites: Definition, History and Scholarship, http://jemc.indiana.edu/vol13/issue1, accessed April 20, 2010 